\title{
KAJIAN KURIKULUM SEKOLAH ALAM DALAM RANGKA MEWUJUDKAN PENDIDIKAN KARAKTER SISWA TINGKAT SEKOLAH DASAR
}

\author{
Yulianti dan Prihatin Sulistyowati \\ Email : yuliantimalang2@gmail.com
}

\begin{abstract}
Abstrak: Kurikulum dan pembelajaran, merupakan dua hal yang tidak dapat dipisahkan. Sebagai suatu rencana atau program, kurikulum tidak akan bermakna manakala tidak diimplementasikan dalam bentuk pembelajaran. Demikian juga sebaliknya, tanpa kurikulum yang jelas sebagai acuan, maka pembelajaran tidak akan berlangsung secara efektif (Sanjaya: 2009). Apa yang dideskripsikan dalam kurikulum harus memberikan petunjuk dalam proses pembelajaran di dalam kelas; dan apa yang terjadi di dalam kelas merupakan masukan yang dapat dijadikan bahan pertimbangan dalam penyempurnaan kurikulum.Sekolah dasar Islam (SDI) Surya Buana Malang salah satu sekolah dasar di kota Malang yang mempunyai karakter yang berbeda dengan sekolah Dinas lainnya. Penelitianinibertujuanuntukmengetahui dan mendeskripsikanapa konsep sekolah alam di SD Islam Surya Buana Malang dan bagaimana implementasinya dalam mewujudkan pendidikan karakter siswa tingkat sekolah dasar. Metode penelitian yang digunakan adalah metode penelitian kualitatif. Penelitian ini menggunakan pendekatan kualitatif dengan rancangan penelitian studi kasus observasional yang berkenaan dengan konsep pengembangan kurikulum Sekolah Alam Bilingual SDI Surya Buana Malang. Teknik pengumpulan data yaitu: (1) wawancara mendalam (2) observasi partisipan dan (3) studi dokumentasi. Analisis data yang digunakan dalam penelitian ini: reduksi data, penyajian data, dan penarikan kesimpulan atau verifikasi. Hasil penelitian menunjukkan bahwa sekolah dasar Islam SDI Surya Buana Malang menerapkan kurikulum Diknas dengan mengaplikasikan konsep kurikulum sekolah alam "Triple R", dan dalam pembinaan karakter siswa SDI Surya Buana Malang menggunakan buku penghubung antara guru dan orang tua.
\end{abstract}

Kata Kunci: kurikulum, sekolah alam, pendidikan karakter.

\section{PENDAHULUAN}

Kurikulum merupakan salah satu komponen yang memiliki peran penting dalam sistem pendidikan, sebab dalam kurikulum bukan hanya dirumuskan tentang tujuan yang harus dicapai sehingga memperjelas arah pendidikan, akan tetapi juga memberikan pemahaman tentang pengalaman belajar yang dimiliki setiap siswa.

Kurikulum dan pembelajaran, merupakan dua hal yang tidak dapat dipisahkan. Sebagai suatu rencana atau program, kurikulum tidak akan bermakna manakala tidak diimplementasikan dalam bentuk pembelajaran. Demikian juga sebaliknya, tanpa kurikulum yang jelas sebagai acuan, maka pembelajaran tidak akan berlangsung secara efektif (Sanjaya: 2009). Sehingga dapat diambil kesimpulan bahwa kurikulum dan pembelajaran bagaikan dua sisi dari satu mata uang. Keduanya sangat penting dan saling membutuhkan. Apa yang dideskripsikan dalam kurikulum harus memberikan petunjuk dalam proses pembelajarn di dalam kelas; dan apa yang terjadi di dalam kelas merupakan masukan yang dapat dijadikan bahan pertimbangan dalam penyempurnaan kurikulum.

Gambaran Sekolah Dasar Islam (SDI) Surya Buana Malang sebagai salah satu sekolah formal yang menerapkan pengembangan kurikulum yang bersumber dari kurikulum nasional Departemen Pendidikan Nasional. Salah satu konsep pendidikan yang dikembangkan oleh Sekolah Dasar Islam (SDI) Surya Buana adalah memadukan antara kurikulum Kementrian dan kurikulum Diknas dengan menerapkan 
konsep pengembangan kurikulum sekolah alam yang mempunyai desain yang berbeda dengan sekolah alam lainnya. Adapun muatan mata pelajaran yang diberikan di SDI Surya Buana Malang sesuai dengan struktur kurikulum yang terdapat dalam Standar Isi dengan jumlah jam penambahan. Ada 4 kelompok mata pelajaran di SDI Surya Buana tahun pelajaran 2013/2014 yaitu mata pelajaran inti, muatan lokal, mata pelajaran Plus dan pengembangan diri.

a. Mata pelajaran inti, meliputi; pendidikan agama, pendidikan kewarganegaraan, bahasa Indonesia, matematika, IPA, IPS, seni budaya dan keterampilan, penjaskes dan Orkes.

b. Muatan Lokal, meliputi; bahasa daerah, bahasa Inggris dan TIK.

c. Mata pelajaran Plus; Tilawati dan hafalan dan Parents Day.

d. Pengembangan Diri

Konsep sekolah alam ini yaitu memberikan pembelajaran pada anak sesuai dengan alamnya anak atau sesuai dengan perkembangan psikologi anak (Eve Readety, 2008). Sekolah alam Jakarta mengembangkan kurikulum dengan menggunakan konsep Spider web, sekolah alam Cikeas mengembangkan konsep kurikulum akhlak, logika, dan leadership. (www. sekolah alam Cikeas. org/ Diakses Rabu, 7 Maret 2010). Sekolah alam Bogor mengembangkan konsep Learning by Qudwah, Expreriental Learning, konsep Pengembang an kepemimpinan dengan metode Outbond Training, dan Pengembangan kemampuan berwirausaha. Sedangkan sekolah alam Bandung mengembangkan intisari pendidik an mengacu kepada 3 (tiga) aspek utama: Ketakwaan - Keilmuan dan Kepemimpinan (www. sekolahalamBandung. Org/ Diakses Rabu, 7 Maret 2010).

Dari paparan di atas peneliti tertarik untuk melakukan penelitian terhadap kajian kurikulum yang ada di Sekolah Dasar Islam (SDI) Surya Buana yang berjudul "Kajian Kurikulum Sekolah Alam dalam Rangka
Mewujudkan Pendidikan Karakter Siswa di Tingkat Sekolah Dasar: Studi Kasus di Sekolah Alam Bilingual SDI Surya Buana Malang."

\section{PEMBAHASAN}

\section{PengertianKurikulum}

Istilah kurikulum digunakan pertama kali pada dunia olahraga pada zaman Yunani kuno yang berasal dari kata curir dan curere. Pada waktu itu kurikulum diartikan sebagai jarak yang harus ditempuh oleh seorang pelari. Orang mengistilahkannya dengan tempat berpacu atau tempat berberlari dari mulai start sampai finish (Sanjaya, 2009: 3). Sehingga dapat ditarik kesimpulan kurikulum merupakan alat yang sangat penting dalam menjamin keberhasilan proses pendidikan, artinya tanpa kurikulum yang baik dan tepatkan sulit mencapai tujuan dan sasaran pendidikan yang dicita-citakan.

\section{LandasanKurikulum}

Nana Sudjana menyebutkan ada 3 hal pokok yang menjadi landasan dalam pelaksanaan, pembinaan dan pengembangan kurikulum, yakni: (1) Landasan Filosofis, yang dimaksud cara berfikir yang radikal dan menyeluruh secara mendalam kajian filsafat tentang hakekat manusia, apa sebenarnya manusiaitu, apa hakekat hidup manusia, apa tujuan hidupnya dan sebagainya yang mencakup logika, etika dan estetika. Kaitannya dengan kurikulum dari ketiga pandangan tersebut sangat diperlukan terutama dalam menerapkan arah dan tujuan pendidikan; (2) Landasan Sosial Budaya, yang mana kurikulum pendidikan harus dan sewajarnya pula dapat menyesuaikan bahkan dapat mengantisipasi kondisi-kondisi yang bakal terjadi di samping perlu penyesuaian dengan kondisi masyarakat; (3) Landasan Psikologis, yang mana mendidik berarti mengubah tingkah laku anak menuju kedewasaan. Semua ini dalam proses belajar mengajar selalu dikait- 
kan denganteori-teori perubahan tingkah laku anak (Sanjaya, 2009:42).

\section{KomponenKurikulum}

Beberapa ahli pendidikan mengemukakan bahwa dalam rangka pengembangan kurikulum maka perlu diperhatikan beberapa komponen yang menurut Nasution, diantaranya adalah : 1) tujuan, 2)bahan pelajaran, 3) proses belajar mengajar, dan 4) penilaian. Sedangkan Hamalik mengemukakan bahwa pengembangan kurikulum yang dilakukan hendaklah mencakup : 1) tujuan kurikulum, 2) materikurikulum, 3) metode kurikulum, 4) organisasi kurikulum dan 5) evaluasi kurikulum.

\section{Prinsip-Prinsip Kurikulum}

Agar kurikulum dapat berfungsi sebagai pedoman, maka ada sejumlah prinsip dalam proses pengembangannya.

Di bawah ini akan diuraikan sejumlah prinsip yang dianggap penting, sebagaimana yang dikemukakan oleh beberapa ahli, diantaranya menurut Abdullah Idisebagai berikut:1) Prinsip Relevansi; 2) Prinsip Efektifitas; 3) Prinsip Efisiensi; 4) Prinsip Kontinuitas (Kesinambungan); 5) Prinsip Fleksibilitas (Keluwesan); 6) Prinsip Berorientasi Tujuan; 7) Prinsip dan Model Pengembangan Kurikulum. Kesimpulannya dalam implementasi kurikulum butuh prinsipprinsip yang mendasar sebagai acuan pokok pelaksanaan dalam kegiatan pembelajaran. Tanpa prinsip yang jelas maka kurikulum tidak akan terlaksana dengan baik, karena arah atau tujuan yang dijadikan pedoman masih belum ada.

\section{Dasar-dasar Kurikulum}

Kurikulum merupakan wahana belajar mengajar yang dinamis sehingga perlu dinilai dan dikembangkan secara terus dan berkelanjutan sesuai dengan perkembangan yang ada dalam masyarakat. Perkembangan kurikulum adalah suatu proses yang menentukan bagaimana pembuatan kurikulum akan berjalan. Berikut ini adalah dasardasar pengembangan kurikulum; a). Kuri- kulum disusun untuk mewujudkan sistem pendidikan nasional. b). Kurikulum pada semua jenjang pendidikan dikembangkan dengan pendekatan kemampuan. c). Kurikulum harus sesuai dengan ciri khas satuan pendidikan pada masing-masing jenjang pendidikan. d). Kurikulum pendidikan dasar, menengah, dan tinggi dikembangkan atas dasar standar nasional pendidikan untuk setiap jenis dan jenjang pendidikan. e). Kurukulum pada semua jenjang pendidikan dikembangkan secara berdiversifikasi sesuai dengan kebutuhan potensi peminat peserta didik dan tuntutan pihakpihak yang memerlukan dan berkepentingan. f). Kurikulum dikembangan dengan memperhatikan tuntutan pembangunan daerah dan nasional, keanekaragaman potensi.

\section{Gambaran Kurikulum Sekolah Alam}

Konsep pengembangan kurikulum sekolah alam berbeda-beda. Sekolah alam Jakarta mengembangkan kurikulum dengan menggunakan konsep spider web, sedangkan sekolah alam Cikeas mengembangkan kurikulum akhlak, logika dan leadership (www. Sekolah alam Cikeas. org. Dikases 7 Maret 2010). Sedangkan sekolah alam SDI Surya Buana menerapkan kurikulum berbasis triple "R" yaitu reasoning (penalaran), research (penelitian), dan religion (agama).

\section{PENUTUP}

Konsep kurikulum sekolah alam SDI Surya Buana Malang mengintegrasi atau memadukan antara mata pelajaran umum dengan mata pelajaran agama antara buku pegangan guru dan siswa berdasarkan pada kurikulum kementerian kebudayaan dan pendidikan dengan berasaskan pada konsep sekolah alam Triple " $\mathrm{R}$ " yaitu reasoning (penalaran), research (penelitian), dan religius (agama).

Pelaksanaan pendidikan karakter di sekolah alam SDI Surya Buana Malang di- 
integrasikan dalam proses pembelajaran mata pelajaran dan dalam kegiatan ekstrakurikuler seperti acara kegiatan pramuka, PMI dan seterusnya. Kegiatan pembinaan karakter tersebut di evaluasi melalui buku penghubung antara guru dengan orang tua yaitu, buku informasi, buku IMTAK, dan buku pegangan hafalan do'a yang ditargetkan pada setiap tingkatan kelas.

\section{DAFTAR PUSTAKA}

Anggota IKAPI Kampus UNESA, 2011, Bunga Rampai Pendidikan Karakter Stategi Mendidik Generasi Masa Depan, UNESA UNIVERSITY PRESS, Cet.I

Bungin, Burhan. 2007. Penelitian Kualitatif. Jakarta: Kencana Prenada Media Group.

Faisal, Sanapiah. 2006. Penelitian Kualitatif; Dasar-dasar dan Aplikasi. Malang: Yayasan Asah Asih Asuh.

Komunitas Sekolah Alam. 2005. Menemukan Sekolah Yang Membebaskan. Tangerang: Kawan Pustaka.

Kurikulum Sekolah Dasar Islam (SDI) Surya Buana Malang, 2013. Yayasan Bahana Cita Persada Malang.

Moleong, Lexy J. 2000. Metodologi Penelitian Kualitatif, Bandung: PT Remaja Rosdakarya.

Mulyasa, E. 2007. Kurikulum Tingkat Satuan Pendidikan. Bandung: PT. Remaja Rosdakarya.

Muslich, Mansur. 2007. KTSP, Pembelajaran Berbasis Kompetensi dan Kontekstual. Jakarta: PT. Bumi Aksara.

Nasution, S. 2006. Asas-Asas Kurikulum, Jakarta: BumiAksara, Cet. VII.

Sanjaya, Wina. 2009. Kurikulum dan Pembelajaran (Teori dan Praktik Pengembangan Kurikulum Tingkat Satuan Pendidikan/ KTSP ), Jakarta: PT. Kencana Prenada Media Group.
Supriyadi, Dedi. 2004. Membangun Bangsa Melalui Pendidikan. Bandung: PT. Remaja Rosdakarya.

Samani, Muchlas dan Hariyanto, 2012, Konsep dan Model Pendidikan Karakter, Bandung: PT. Remaja Rosdakarya.

Sajirun,Muhammad. 2012, Membentuk Karakter Islami Anak Usia Dini, Solo: PT. Era Adicitra Intermedia, Cet.I

Sulistyowati, Endah. 2012, Implementasi Kurikulum Pendidikan Karakter, Yogyakarta: PT. Citra Aji Parama.

Undang-undangRepublik Indonesia No. 20 Tahun 2003. Sistem Pendidikan Nasional. Bandung: Citra Umbara.

Zuhairini \& Ghofir, Abdul. 2004. Metodologi Pembelajaran Pendidikan Agama Islam. Surabaya: UM Press. 